\title{
Agnieszka Haska
}

Instytut Filozofii i Socjologii PAN

orcid.org/0000-0003-0545-5250

ahaska@ifispan.waw.pl

\section{Piotr Forecki, Po Jedwabnem. Anatomia pamięci funkcjonalnej, Warszawa: Wydawnictwo IBL PAN, 2018, 434 s.}

24 marca 2019 r., w ramach obchodów Narodowego Dnia Pamięci Polaków ratujących Żydów pod okupacją niemiecką, w Sadownem na Mazowszu odbyła się uroczystość upamiętnienia rodziny Lubkiewiczów, zorganizowana przez Instytut Solidarności i Męstwa im. Witolda Pileckiego. Wśród zaproszonych gości znajdował się m.in. premier Mateusz Morawiecki, który wygłosił krótkie przemówienie. Zawierało ono kilka doskonale znanych elementów narracji o Sprawiedliwych. Przede wszystkim heroizm jednostek zamieniono w heroizm narodowy, a przypadek rodziny Lubkiewiczów stał się przykładem postawy całego społeczeństwa polskiego wobec Żydów w czasie okupacji - takich miejsc jak Sadowne są „setki, może tysiące”. Jak stwierdził premier, „Żyd, który spotkał Niemca, stawał się martwym Żydem, a Żyd, który spotkał Polaka, miał szansę przeżyć" ${ }^{2}$, co jest z jednej strony daleko idącym uogólnieniem, z drugiej zaś elementem stale używanym do biało-czarnego opisu okupacyjnej rzeczywistości Zagłady (i złośliwie można zapytać, a co z Austriakami?). Heroizm Polaków oczywiście nie może się równać z heroizmem innych, gdzie indziej bowiem „karą za ratowanie Żydów była karą więzienia”, a więc „nie ma równowagi i porównania do tych wielkich czynów Polaków, którzy ratowali swoich żydowskich sąsiadów, żydowskich współobywateli”. Trzeba o tym powiedzieć „głośno całemu światu”; podkreślono zatem, że „wbrew różnym oszczerstwom, które się pojawiają, liczne źródła przemawiają za pozytywną rolą Polaków podczas II wojny światowej”3. A jeśli źródła nie wystarczą, to taka właśnie jest „logika faktów tamtych czasów", cokolwiek miałoby to znaczyć.

Przemówienie Mateusza Morawieckiego to jeden z niezliczonych przykładów „polityki wobec pamięci” ostatnich lat, opartej na budowaniu narodowego i politycznego mitu; z ekstrapolacji, uogólnień, przeinaczeń, półprawd, a niekiedy wręcz kłamstw historycznych jest sklejana narracja o Zagładzie, relacjach pol-

${ }^{1}$ https://www.premier.gov.pl/multimedia/wideo/premier-mateusz-morawiecki-podczasodloniecia-tablicy-pamiatkowej-rodziny.html (dostęp 27 III 2019 r.).

${ }^{2}$ Ibidem.

${ }^{3}$ Ibidem. 
sko-żydowskich w czasie okupacji, kształtująca pamięć o drugiej wojnie światowej. Mit ten i sposoby jego funkcjonowania w dyskursie publicznym dekonstruuje i analizuje w swojej najnowszej książce Po Jedwabnem. Analiza pamięci funkcjonalnej Piotr Forecki. Podobnie jak w przypadku poprzedniej publikacji, Od "Shoah" do „Strachu”, , Forecki wykonał gargantuiczną pracę dokumentacyjną, która stała się podstawą do nakreślenia szczegółowego obrazu reaktywnej i defensywnej „polityki wobec pamięci”. Ogrom materiału źródłowego może z początku przerażać, ale Forecki sprawnie i wręcz brawurowo prowadzi czytelnika przez kolejne warstwy interpretacyjne, nadając swojej analizie przejrzystą strukturę.

Fundamentem jest tu zapożyczone z krytyki feministycznej i spopularyzowane przez Susan Faludi pojęcie backlashu. Backlash, przetłumaczony na język polski przez Annę Dzierzgowską jako „reakcja”, to dosłownie odrzut kolby po wystrzale z broni palnej; jako narzędzie analityczne zaś mieści w sobie zarówno zwykłe reakcje, jak i te konserwatywne - kontratak, sprzeciw, próbę powrotu do dawnego porządku sprzed wydarzenia, które zmieniło dyskurs publiczny. Tym wydarzeniem węzłowym w wypadku dyskursu o Zagładzie jest, rzecz jasna, książka Jana Tomasza Grossa Sąsiedzi i jej efekt w postaci debaty jedwabieńskiej. Jak dowodzi Forecki, naruszyła ona „konstrukcję nośną polskiej tożsamości" (s. 29), w związku z czym nastąpiło rozłożone w czasie kontruderzenie. Za „utraconym bezpiecznym miejscem w hilbergowskiej triadzie” (s. 19) nie poszły przepracowanie i internalizacja tego doświadczenia, wręcz przeciwnie - w Polsce po Jedwabnem „różnymi metodami i zbiorowym wysiłkiem [...] funduje się Polakom bilety powrotne do Polski sprzed 2001 roku" (s. 110). Forecki analizuje strategie, narzędzia i praktyki backlashu jako spektrum praktyk pamięci funkcjonalnej (za Aleidą Assmann), mające służyć przywróceniu i umocnieniu dawnego wariantu tożsamości zbiorowej i konsolidacji wspólnoty, w których kluczową rolę odgrywa państwo ze swoją hegemoniczną polityką pamięci i zapominania.

Książka jest podzielona na trzy części. W pierwszej oprócz dokładnego wyjaśnienia wspomnianych wcześniej założeń metodologicznych Forecki zajmuje się rozpoznaniem genezy pojedwabieńskiego backlashu, rekonstruując jego słownik, naturę oraz główne elementy. Dla pierwszej fazy kontruderzenia - na co wskazuje analiza tekstów powstałych do 2007 r. - poza dezawuowaniem i wymazywaniem Jedwabnego kluczowe okazuje się pojęcie „patriotyzmu afirmatywnego”, a miał się on przeciwstawiać „patriotyzmowi krytycznemu”. „Wspólnotę wstydu” - jak pisali Kazimierz Michał Ujazdowski i Tomasz Merta m.in. w tekście Odzyskać pamięć, opublikowanym w „Rzeczpospolitej” w 2003 r. - miała zastąpić „wspólnota dumy” (s. 59-60), którą planowano budować wokół chlubnych kart polskiej historii. Na postulatach, jak wiadomo, się nie skończyło

${ }^{4}$ Piotr Forecki, Od „Shoah” do „Strachu”. Spory o polsko-żydowska przeszłość i pamięć w debatach publicznych, Poznań: Wydawnictwo Poznańskie, 2010. 
- afirmacja narodowej historii została wpisana do programu Prawa i Sprawiedliwości i - jak przypomina Forecki - po 2005 r. stała się jedną z zasad konstruowania nie tylko nowego porządku moralnego, lecz także narzędziem takiego opisu rzeczywistości, by wszystko to, co podaje w wątpliwość brak skalania polskiej tożsamości i historii, zostaje uznane w najlepszym wypadku za „zmasowaną dezinformację" (s. 61), a w nieco ostrzejszym wariancie - za atak na Polskę i Polaków. Forecki analizuje wypowiedzi publiczne oraz politykę instytucjonalną, w której jednym ze zworników backlashu stał się kult „żołnierzy wyklętych”, z jednej strony konsolidujący wspólnotę przez skoncentrowanie jej na honorze, polskości i patriotyzmie (pomijając wszystkie wątpliwości historyczne), z drugiej zaś odwracający uwagę od powojennych zbrodni dokonanych na Żydach. Ważnymi elementami budowy narodowego mitu i dominującej opowieści o drugiej wojnie światowej okazały się również holokaustyzacja polskiej martyrologii oraz polonizowanie Zagłady. Co jednak najważniejsze, Forecki dobitnie pokazuje, że backlashu nie zatrzymały zmiany polityczne; kontruderzenie trwało bez względu na to, kto był u władzy.

Widać to zwłaszcza w drugiej i trzeciej części książki, poświęconych odpowiednio rewizjonizmowi historycznemu wobec udziału Polaków w Zagładzie i Rzeczypospolitej Sprawiedliwych. Opisując na niezliczonych przykładach strategie backlashu, wymazywania i zapomnienia stosowane wobec Jedwabnego, Forecki pokazuje nie tylko, do jakich środków sięgnięto, lecz przede wszystkim jak odpowiedzialność jest przenoszona ze sprawców na ofiary i w jaki sposób kształtował się wątek żydowskich win wobec Polaków. Autor sięga zarówno do dyskursu publicznego, jak i do wyników sondaży zamawianych m.in. przez Centrum Badań nad Uprzedzeniami, w których ramach sprawdzano postawy społeczne oraz poziom antysemityzmu wtórnego. Forecki analizuje również pod kątem symptomów backlashu podręczniki szkolne; z tej części książki wyraźnie wynika jednorodny obraz - ,jakby jedna ręka prowadziła wszystkie pióra” (s. 253). Rywalizacja cierpienia, wątek przypominania żydowskich win i zapominania polskich, ekstrapolacja i wyolbrzymianie pomocy udzielanej Żydom pojawia się bowiem wszędzie - podobnie jak wymazywanie żydowskiego głosu (chyba że jest on używany jako figura potwierdzająca obowiązującą narrację). Jeszcze wyraźniej widać to w odniesieniu do Sprawiedliwych, na różne sposoby i w różnych konfiguracjach wykorzystywanych instrumentalnie. Jak wskazuje Forecki, stali się oni najważniejszym narzędziem nowej polityki historycznej, a wręcz oddzielną gałęzią przemysłu pamięci. Wszystko to służy konstruowaniu alternatywnej wersji historii i przekonaniu o narracyjności przeszłości. Mówiąc krótko, nie liczą się fakty, ale tworzone mity - a historia jest przedstawiana jako narracje, które ze sobą konkurują.

Książka Foreckiego to nie tylko znakomite źródłowo i analitycznie omówienie najważniejszych elementów konstruowania nowej narracji o Zagładzie i polityki wobec pamięci, lecz przede wszystkim zasługująca na podziw synteza jednego z najważniejszych tematów debaty publicznej ostatnich bez mała dwudziestu 
lat. Synteza tym trudniejsza, że uchwycone zjawiska są do pewnego stopnia opisywane in statu nascendi, a brak dystansu, co oczywiste, mógł utrudniać zadanie. Po Jedwabnem nie ma zakończenia - ale i nie może go na razie mieć. Wszystkie podstawowe cechy backlashu: patriotyzm afirmatywny, rewizjonizm historyczny, kult Sprawiedliwych, uwidoczniły się z całą ostrością podczas dyskusji wywołanej nowelizacją ustawy o IPN czy po opublikowaniu tomów Dalej jest noc. Wydawałoby się, że rok 2018 był pod różnymi względami przełomowy, chociażby dlatego że do tej pory polski backlash nie wywoływał międzynarodowych awantur. Ale, jak pokazują m.in. wypowiedzi polityków takie jak ta przywołana na początku recenzji, strategie backlashu mają się świetnie, a jego architekci i „pośrednicy”, jak ich nazywa Forecki, wciąż pracują nad umacnianiem „jedynie słusznej" narracji o Zagładzie. Złudna okazała się też zmiana w polskiej świadomości, której zwiastunem miało być to, że w zeszłorocznych dyskusjach zamiast pytania „czy Polacy mordowali Żydów?” częściej zaczęło się pojawiać pytanie „ilu Żydów zamordowali Polacy?”. Forecki udowadnia jednak niezbicie, że pamięć magazynująca - czyli ta zamknięta w archiwach i publikacjach naukowych - nie ma szans konkurować z pamięcią funkcjonalną, w której wiedza historyczna jest poddawana manipulacji przy użyciu różnorodnych strategii backlashu. Konstruowanie narodowego mitu, do czego wykorzystuje się aparat państwowy i wszelkie dostępne narzędzia, stało się jednym z podstawowych celów politycznych w kształtowaniu tożsamości Polaków. Na marginesie lektury Foreckiego można się też zastanawiać, w jakiej mierze powrót do starannie wyobrażonej przeszłości - czyli, używając pojęcia Zygmunta Baumana, swoista retrotopia - nie jest wyłącznie polską specyfiką. Konstruowanie poczucia wspólnoty wokół wyidealizowanej wizji tego, co było, staje się przecież wyraźnym elementem krajobrazu społecznego i politycznego nie tylko w Europie Środkowo-Wschodniej, lecz także w Wielkiej Brytanii czy Stanach Zjednoczonych. Na polskim podwórku objawia się to zwłaszcza w odniesieniu do historii najnowszej przez mitologizację Drugiej Rzeczypospolitej czy właśnie heroizm narodowy podczas drugiej wojny światowej. Podważanie owej retrotopii, przypominanie o mniej szlachetnych kartach historii, winie i wstydzie czy nawet przywracanie żydowskich głosów $\mathrm{z}$ ich odmienną perspektywą, traktowane jako podważanie tożsamości wspólnoty, zagrażają przede wszystkim porządkowi wykreowanego świata. Jest to na pewno wyzwanie dla tych wszystkich, którzy nie traktują Zagłady jako czarno-białej opowieści o ofiarach i bohaterach, a historii jako szwedzkiego stołu, z którego można wybrać tylko to, na co ma się aktualnie apetyt. 